\title{
A PARADIGM FOR RESTENOSIS AFTER ANGIOPLASTY: CLUES FOR THE DEVELOPMENT OF NEW PREVENTIVE THERAPIES
}

\author{
James S. Forrester, Michael Fishbein, Richard Helfant, James Fagin \\ Cedars - Sinai Medical Center, Los Angeles USA
}

\begin{abstract}
- Restenosis after intravascular interl>ention is one of the most important unsolved clinical and economic problems in the management of cardiovascular disease. Although neither its pathogenesis nor its prevention are yet defined, the early and late histologic appearance of the angioplasty state are known. Immediately after angioplasty, theatherotna has fissures, and the normal segment of the vessel circumference is stretched. There is substantial evidence of intimal injury. When restenosis develops at 1-4 months the histologic appearance of the restenotic lesion is intimalhypetplasia. Given this endpoint, we may theorize that the proximate cause of this response is denuding and stretching vascular injury. Since the healing response to tissue injury has been studied extensively, we can hypothesize the major milestones in the temporal sequence of restenosis are platelet aggregation, inflammatory cell infiltration, release of growth factors, medial smooth muscle cell modulation and proliferation, proteogfycan synthesis and extracellular matrix remodelling. At each of these steps, there are potential inhibitors. The resolution of the problem of restenosis may require both removal of atheroma mass and appropriate timing and effective delivery of inhibitors of intimal hyperplasia to the injury site in adequate concentration.
\end{abstract}

\section{INTRODUCTION}

- Between 1980 and 1989, the estimated volume of percutaneous transluminal coronary angioplasty (PTCA) procedures increased twenty fold from 10,000 to 225,000 per year. Trend analysts predict the volume will double again by the mid 1990 's (1). Restenosis, the major problem following angioplasty has been reported from the National Heart, Lung, and Blood Institute registry and from indi- vidual high volume angioplasty centers to be $25-55 \%$ (2$6)$. Beyond the adverse outcome itself this problem has serious economic impact, since its treatment is often reangioplasty in economic terms one of every three PTCA procedures performed generates the potential need for a fourth PTCA. Thus at one of the nation's leading angioplasty centers, 37\% of the PTCAs were repeat procedures (7).

Central to the problem of restenosis is that its pathogenesis remains uncertain. We believe there is a substantial body of research in oncology, atherogenesis, and wound healing that is relevant to the pathogenesis of restenosis. In this manuscript we will begin by relating these data to the time course and histopathology of coronary restenosis in man. We will then propose a hypothetical schema for the pathogenesis of restenosis, and conclude by discussing the possibilities for its prevention.

\section{THE TIME COURSE OF RESTENOSIS}

- Although a few specific vascular morphologies (e.g., long lesions, complete occlusions and disrupted surfaces) have a higher probability of restenosis (8), coronary angiography has been of little value for predicting in which individual lesions restenosis will occur. Serial coronary angiography has, however, defined the time course of restenosis. Nobuyoshi et al repeated coronary angiography in 229 patients at 1,3,6 and 12 months after successful PTCA (3). The actuarial restenosis rate was $13 \%$ at one month, $43 \%$ at 3 months, and $53 \%$ at one year. They concluded that restenosis develops between the first and third month post PTCA. This conclusion has been confirmed by Serruys et al who performed quantitative coronary angiography at a single predetermined followup time of 1,2,3, or 4 months in 342 patients (4). Like Nobuyoshi 
et al, they found the most substantial change in lumen diameter occured between the second and thrd months. Serruys et al also made the important observation that "almost all lesions deteriorate to some extent by 120 days post PTCA". Thus, whereas prior angiographic studies used categorical cutpoints to define restenosis as present or absent, these data suggest that restenosis is an expected or "normal" biologic response which varies in magnitude. This seemingly semantic distinction may be critical to our understanding of restenosis, as we will describe below.

\section{THE IMMEDIATE AMD LATE CONSEQUENCES OF PTCA}

- Angiography is a relatively insensitive method for detecting intimal injury (9). Accordingly, coronary angioscopy has recently beenused before, during and after balloon angioplasty (Table 1). Uchida et al found that whereas $64 \%$ of PTCA sites appeared angiographically normal immediately after PTCA, all had angioscopic evidence of intimal trauma (10), a finding confirmed by Mizunoet al (11). These angioscopic data are concordant with postmortem studies of patients dying within 30 days of PTCA, which consistently show that even in angiographically successful angioplasty there is a high incidence of intimal dissection, hemorrhage and thrombus formation (12-25). The largest single study, by Potkin et al, found that $95 \%$ of angiographically successful angioplasties had evidence of extensive intimal damage (19). This histologic finding presumably is the counterpart of the surface dismption with hemorrhage and thrombus formation observed by in vivo angioscopy. We can conclude that PTCA causes substantial intimal injury that is not detected by angiography.

There is a second, even less readily detected imme-

Table 1:

ANGIOSCOPIC DETECTION OF PTCA-INDUCED INJURY

AUTHOR $\mathrm{n}$ THROMBI DISSECTION HEMORRHAGE NORMAL ANGIO

\begin{tabular}{lccccc}
\hline Uchida & 11 & 10 & 10 & 5 & 7 \\
Mizuno & 9 & 6 & 8 & 5 & - \\
\hline
\end{tabular}

diate effect of PTCA. Approximately $70 \%$ of coronary lesions are eccentric, such that the circumference of the atherosclerotic vessel consists of two segments: the atheroma and the relatively normal vessel wall. The force of balloon dilatation has different effects on the two segments. The atheroma, being stiff and noncompressible, develops fissures, most commonly at the junction between the normal segment of the vessel and atheroma (Fig. 1) (16-19).

The distending force of the balloon also can markedly increase the length of the normal segment, and may be sufficient to tear apart the media (16). This finding is important, because the actual increase in cross sectional area resulting from even fissures in the atheroma is quite

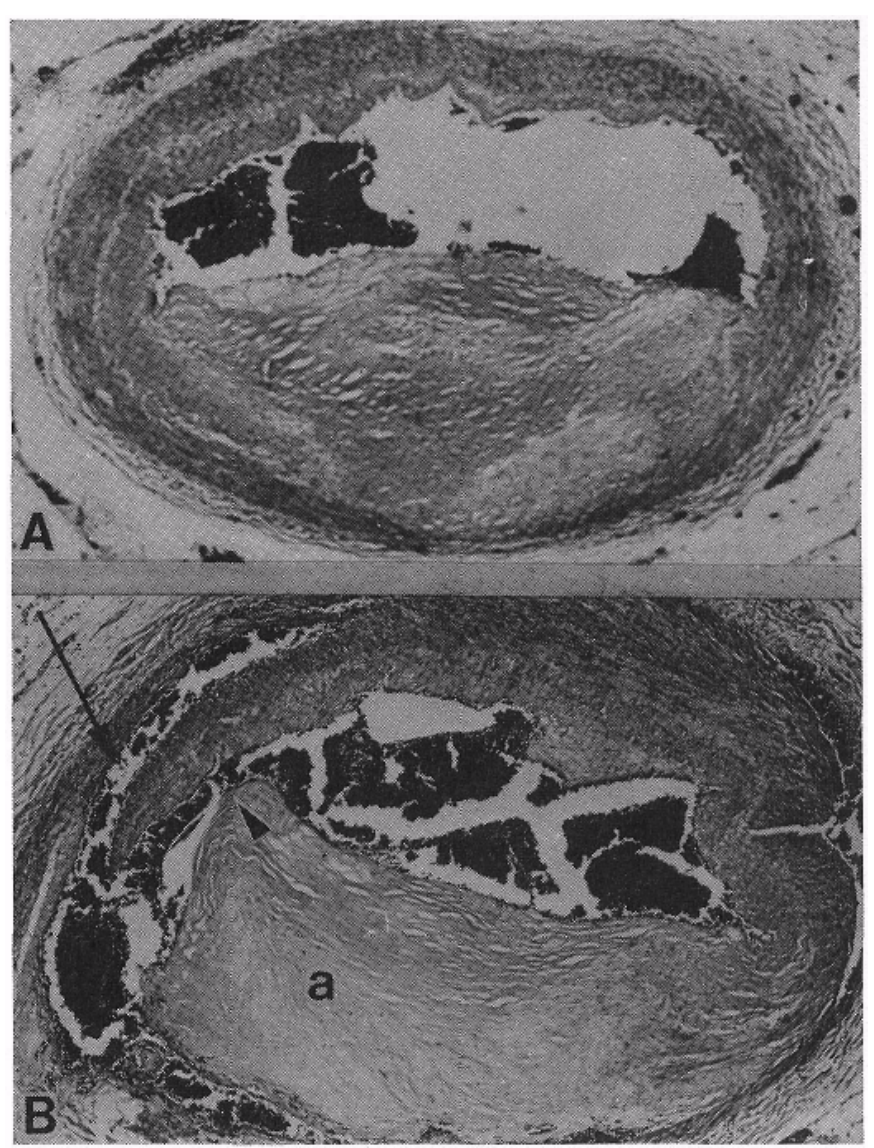

FIGURE 1: Segments of right coronary artery from a patient who died after emergency PTCA followed by bypass surgery for massive myocardial infarction. A: Proximal non-treated segment; B) Segment from balloon angioplasty site showing of separation of atheroma (a) from adjacent normal arterial wall (arrowhead) with dissection of blood through disrupted media (arrow) (H\&E stain, X25).

small (19). Thus although most investigators have concluded that fissuring causes the evident immediate improvement in angiographic lumen diameter after angioplasty, it now seems likely that "fissure" hypothesis is incomplete. Postmortem fixation obscures the stretching effect of balloon dilation because the normal segment co'ntracts during fixation (26). Thus the less readily recognized immediate effect of balloon dilation is stretching of the normal segment of the vessel wall (16-18).

\section{INTIMAL INJURY AND INCREASED SEGMENT LENGTH: STIMULI FOR HYPERPLASIA}

- Our central hypotheses is that these two recognized mechanisms of immediate increase in arterial diameter also are the stimuli to late restenosis. At 1-3 months after PTCA when coronary angiography indicates that restenosis is developing histologic studies consistently show intimal hyperplasia. The intimal hyperplasia is not confined to the 

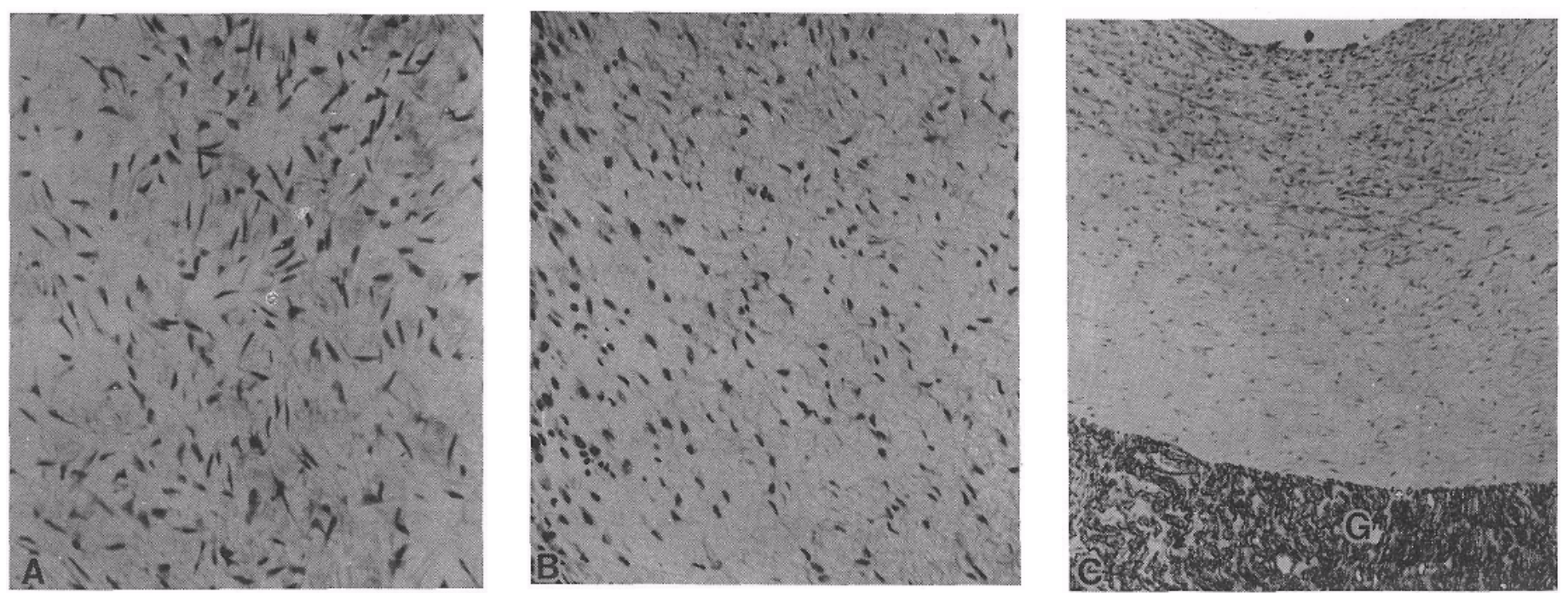

FIGURE 2: photomicrographs of intimal hyperplasia: A-after balloon angioplasty; B-in a dermal scar; and C - (shown at lower magnification) on a synthetic (Gortex) vascular graft (G). Note the histologic similary of the proliferation (A and B x1OO, Cx40).

atheromatous segment of the vessel circumference and often is prominent over the normal segment. This is important because both denuding $(27,28)$ and stretching injury $(29,30)$ are potent stimuli to intimal hyperplasia of normal vessels in animal studies. Thus post-PTCA angiographic narrowing and intimal hyperplasia of both the normal and atherosclerotic segments suggest that restenosis is a generalized response to vascular injury, which is not dependent upon the presence of atherosclerosis.

This concept that restenosis is due to a localized hyperplastic response to injury is supported by in vivo human studies. There have now been a number of patients who developed restenosis after their first atherectomy, in whom the procedure was repeated (31). Examined microscopically, these tissue samples of restenosis, are quite striking. There often is a sharp linear demarcation between the residual atheroma and a newly formed layer of intimal hyperplasia. Histologically this tissue appears to be indistinguishable from post-PTCA intimal hyperplasia. Furthermore, tissue with this same histologic appearance also develops on the inner surface of isolated Dacron grafts in the first three months after placement (Fig. 2) (32). Taken together, we may use the foregoing to infer that the histologic basis of restenosis after PTCA is intimal hyperplasia, which in turn is a normal biologic response to vascular injury.

If restenosis is the vascular manifestation of a general biologic responce to tissue injury, then studies of the molecular and cell biology of wound healing (33) become potentially relevant to its pathogenesis. Wound healing is a generalized biologic response that has been most extensively studied in the skin and the eye. Healing can be described in three overlapping phases (33) inflammation, granulation and matrix formation (Fig. 3). We will first review these three phases, then apply this information to develop a hypothetical construct of restenosis.

\section{THE INFLAMMATORY PHASE OF WOUND HEALING: CELLS AMD GROWTH FACTORS}

- The inflammatory phase begins with coagulation of blood and soluble serum fibronectin to form an extracel-

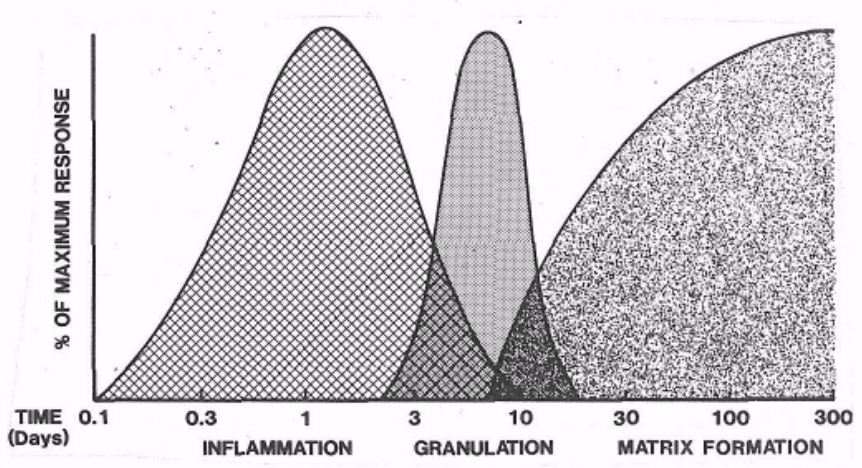

FIG URE 3: The three phases of wound healing. The inflammatory phase begins at the instant of injury and persist for several days. Predominant features of this phase are platelet aggregation, deposition of the fibronectin extracellular matrix, and infiltration of inflammatory cells. The granulation phase overlaps with both the end of the inflammatory phase and the beginning of the matrix remodelling phase. The granulation phase lasts for $1-2$ weeks, and consists predominantly of modulation, migration, and proliferation of mesenchymal cells adjacent to the wound site. The matrix remodelling phase persists for months. It consists of predominantly of proteoglycan deposition, followed by conversation of the extracellular matrix to collagen and elastin. 
lular matrix. Fibronectin has binding domains for both inflammatory cells and biologically active substances that appear in the early phases of wound healing. At the same time platelets aggregate on the wound surface. The activated platelets release substances which promote local vasoconstriction and thrombus formation, and growth factors which activate mesenchymal cells in the vicinity of injured tissue. Within a few hours monocytes also appear, increasing in number over the first few days. Like platelets, monocytes secrete growth factors capable of initiating and promoting local tissue mesenchymal cell migration.

Although their specific roles are incompletely understood, there is 1 ittle doubt growth factors released in the inflmmatory phase play an important role in the second and third phase of wound healing (33-37). Topically applied growth factors, e. g., epidermal growth factor (34), markedly accelerate wound healing in man. Growth factors have many different cellular sources, more than one biologic action, overlapping functions, and serve to potentiate (or inhibit) each other's effects $(35,36)$. With the caveat that the field is quite complex and the, table may be incomplete we have listed growth factors which may play an important role in wound healing and their most important potential roles in restenosis (Table 2).

TABLE 2:

POTENTIAL ROLE OF GROWTH FACTORS IN RESTENOSIS

\begin{tabular}{ll} 
Growth Factor & Potential Action in Restenosis \\
\hline PDGF & Stimulate SMC migration and proliferation \\
FGF & Cause endothelial cell and fibroblast prolifera- \\
tion & $\begin{array}{l}\text { Replace heparin on cell surface, promote SMC } \\
\text { proliferation }\end{array}$ \\
IGF-1 & $\begin{array}{l}\text { Promote SMC proliferation and extracellular } \\
\text { matrix production }\end{array}$ \\
Regulate matrix remodelling, possibly regulate \\
other growth factors
\end{tabular}

Platelet derived growth factor (PDGF), released from the alpha granules of platelets, is a potent stimulus to smooth muscle cell migration and proliferation $(38,39)$. The action of PDGF may not be confined to the early period of inflammation, however, since it also is secreted by activated macrophages and smooth muscle cells. Although PDGF can stimulate smooth muscle cell proliferation independently, it almost certainly does not act alone after tissue injury. PDGF and fibroblast growth factor (FGF) make cells "competent" to be acted upon by a second class of growth factors that cause "progression" to actual DNA synthesis. The latter group include, epidermal growth factor (EGF) and insulin like growth factor I (IGF1) (40-43). Fibroblast growth factor (FGF) is one of the most potent known stimuli to endothelial cell proliferation (40). FGF lacks signal peptide sequences suggesting it is not secreted by cells; it may be activated during the process of binding and release from heparin or other extracellular matrix components. Other growth factors, such as EGF and IGF-1 stimulate mesenchymal cell proliferation $(41,42)$, and EGF competes with heparin for the same cellular binding site (42). Transforming growth factor (TGF) beta may function either as a growth stimulator or a growth inhibitor for different cell types. It also has the ability to regulate differentiated cell function and is probably the most important growth factor in regulation of the extracellular matrix by vascular smooth muscle cells (4447). TGF beta activates gene expression of proteoglycans and collagen, decreases the synthesis of proteolytic enzymes that degrade matrix proteins, and increases the synthesis of cell receptors for matrix proteins (44). Indeed, extracellular matrix synthesis induced by other growth promoters (PDGF, EGF, and FGF) is less than $20 \%$ of that induced by TGF beta (45). Synthesis of chondroitin sulfate, the dominant extracellular matrix protein early in intimal hyperplasia, is increased twentyfold by TGF beta (46).

The temporal sequence of growth factor expression after injury, however, is not yet defined. In our study of growth factor mRNA expression after aortic balloon injury in the rat, we found a twofold increase in PDGF Bchain mRNA and a ninefold induction of IGF-1 mRNA expression beginning at day 3, peaking at day 7 and returning to baseline at 2 weeks (48). Cromack et al have found a substantial increase in TGF beta in healing tissue during the same time period (49). Thus the local tissue level of at least three growth factors is markedly increased during wound healing. While both the cell sources and the details of the interactions among these factors and other cytokines remains to be defined, it is quite likely that locally produced growth factors are a major stimulus for mesenchymal cell migration, proliferation and extracellular matrix production after tissue injury.

\section{THE GRANULATION PHASE OF WOUND HEALING: CELLULAR PROLIFERATION}

- The beginning of local tissue cell migration into the wound site is a convenient marker for the onset of the granulation phase of wound healing (so called because large numbers of newly formed capillaries on the surface impact a granular appearance). The fibronectin extracellular matrix facilitates migration of epithelial or endothelial cells from the wound margin, and fibroblasts or smooth muscle cells from adjacent tissue. Both cell types proliferate. The epithelial or endothelial cells cover the wound surface; the fibroblast and/or smooth muscle cells synthesize new extracellular matrix components, particularly hyaluronic acid and proteoglycans.

The most prominent cell in intimal hyperplasia is the smooth muscle cell. Control of smooth muscle cell proliferation is determined by the actions of mitogens (e.g. 
PDGF, IGF-1) and the opposing effects of inhibitors including TGF beta. Viewed microscopically, the smooth muscle cell has two phenotypes. The contractile phenotype is a quiescent cell with numerous myofilaments. In the normal arterial media it provides both vasomotion and structural support to the vessel. The synthetic phenotype has abundant synthetic organelles (e.g. free ribosomes, Golgi apparatus, rough endoplasmic reticulum). This phenotype is secretory: in particular, it produces extracellular matrix proteoglycan and collagen. Contractile phenotype smooth muscle cells in cell culture are unresponsive to growth factors, whereas appropriately treated synthetic phenotype cells are responsive (50). When tissue is injured, a proportion of the nearby quiescent contractile smooth muscle cells modulate to the more primitive synthetic phenotype which then migrate to the injured area.

The mechanisms responsible for modulation of the smooth muscle phenotype are not known. Both endothelial cells and growth factors probably play an important role. Quiescent endothelial cells inhibit smooth muscle cell growth, but lose this property when they are proliferating. The inhibitory effect is probably meditated by a heparin-like factor of endothelial cell origin, which attaches to the basal lamina of certain mesenchymal cells (51). It is possible that removal of heparin from the smooth muscle cell surface makes it responsive to growth factors $(52,53)$. When the cell is responsive, PDGF alone can stimulate smooth muscle cell migration (38), and several growth factors can stimulate smooth muscle cell proliferation. The stage of cellular proliferation in response to injury lasts roughly a week. It begins to terminate as the surface of the wound is covered by migrating cells, and the third phase of healing begins.

\section{THE MATRIX REMODELLING PHASE OF WOUND HEALING:PROTEOGLYCAN SYNTHESIS}

- The third phase, extracellular matrix deposition and remodeling, continues for months. When the wound surface is covered by a cell layer, mesenchymal cells which migrated into the wound area slow their proliferation and begin to produce large amounts of proteoglycan which replaces fibronectin as the major extracellular matrix component. As the remodelling phase progresses, the proteoglycan is in turn replaced by large fibrous bundles of type I collagen and elastin. Proteoglycans are a diverse group of structurally related macromolecules that are found in the extracellular matrix and in association with the basement and plasma membrane of cells. The common structural elements are a protein backbone to which are attached one or more linear glycosoaminoglycans. Although proteoglycans constitute only about $5 \%$ of the normal vessel dry weight, they are prominent in the extracellular matrix of intimal hyperplasia. Three major vascular proteoglycans are chondroitin sulfate (CSPG), dermatan sulfate (DSPG) and heparin sulfate (HSPG). Smooth muscle cells synthesize CSPG and DSPG, which are the predominant proteoglycans in the extracellular matrix of the healing wound. Both intimal denudation and stretching increase proteogycan synthesis. CSPG and DSPG are central to wound healing because they promote by TGF beta (56). In contrast endothelial cells synthesize predominantly HSPG, which is not controlled by TGF beta (57). The HSPG in the endothelial cell basal lamina probably controls the phenotype of the smooth muscle cell. Since heparin competes with EGF for smooth muscle cell binding sites, it is possible that HSPG exerts its inhibitory effect by preventing growth factor access to the cell surface (53). Alternatively, the antiproliferative effect of heparin may be due to its ability to potentiate the biologic activity of TGF beta by dissociating it from its carrier protein that normally renders it inactive (54). HSPG is present in quiescent smooth muscle cell cultures
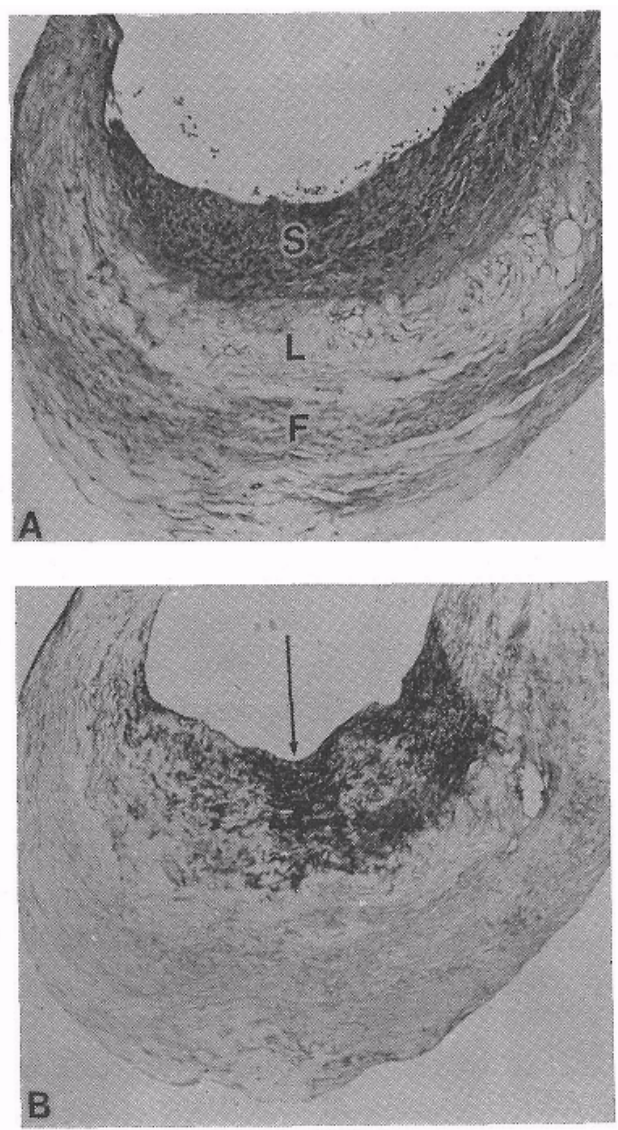

FIGURE 4: Atherectomy specimen from the femoral artery of a patient who developed restenosis after balloon angioplasty. A. Hematoxylin and eosin stained specimen showing 3 zones: $\mathrm{S}$-a superficial zone of smooth muscle cell proliferation (restenosis); $L$ theacellularlipid core of the plaque, and F-the deeper fibrous region.

B. Alcian blue/ PAS stain showing localization of acid mucupolysaccharide material (proteo-) to the re-

gion of intense smooth muscle cell proliferation (arrow) (x40). glycan 
but absent in proliferating cell cultures (52). Although antiproliferative, heparin also markedly stimulates the synthesis of proteoglycans by smooth muscle cells (55).

\section{THE MECHANISM OF RESTEHOS1S: TESTABLE HYPOTHESES}

- We can place restenosis into this wound healing schema since angioscopy and postmortem studies establish that vascular injury is extensive after balloon angioplasty. The serial angiography studies of Nobuyoshi et al, and Serruys et al establish the appearance of restenosis during the third phase of extracellular matrix formation and remodelling $(3,4)$. Autopsy and atherectomy data establish that the histology of the restenotic tissue consists of synthetic smooth muscle cells distributed within a large mass of extracellular matrix $(12,31)$. Special histologic stains show that much of the extracellular matrix is proteoglycan (Fig. 4).

We also know that growth factors are expressed at the vascular injury site, and that these factors stimulate smooth muscle cell proliferation and extracellular matrix synthesis. Thus although the mechanism of vascular restenosis is not known, we can construct a hypothesis for the temporal sequence of restenosis using these data (Fig. 5). muscle cells $(51,52)$. Removal of heparin leads to a change in smooth muscle cell phenotype and makes the cell receptive to the action of growth factors $(50,53)$. The heparin released into the extracellular space also binds PDGF, EGF and FGF locally (58) increasing the local concentration of growth factors. Fibronectin released from plasma forms an early extracellular matrix that, with coagulated blood, fills the fissured areas on the vessel surface (33).

Days 2-4: On day 2 a proportion of the smooth muscle cells in the media begin to increase DNA synthesis (59). PDGF, TGF, and other growth factors released early from platelets and later from macrophages (35), may induce this transformation. Smooth muscle cells proliferate first in the media (50). By day 4, the smooth muscle cells begin to migrate to the injured area, and endothelial cells migrate from the lateral edge of the damaged blood vessel surface $(53,59)$. A principal growth factor for endothelial migration may be FGF(40). The migration of cells induced by growth factors is facilitated by fibronectin and hyaluronic acid in the extracellular matrix (60-62).

Days 5-10: In extensive injury about $30 \%$ of the local smooth muscle cells migrate from the media to the intima, but only about half of the cells that migrate to the wound area proliferate (63). Once in the myointimal

THE MECHANISM OF RESTENOSIS: A HYPOTHESIS

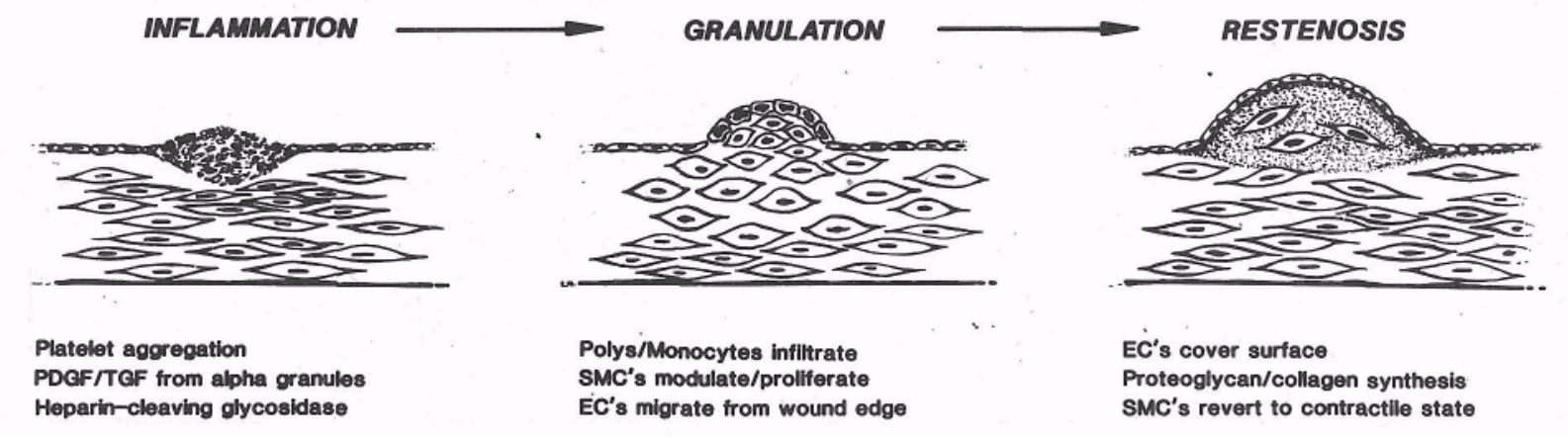

FIGURES: A hypothetical schema for restenosis following injury to the vascular surface. The names of the phases of wound healing have been retained to support the analogy between the two phenomena.

Day 1: Since the atheroma is inelastic, much of the dilating force of the balloon is transmitted to the normal segment of the vascular circumference. When the dilating force exceeds the limit of the normal segment to stretch, tearing begins. Often this occurs at the junction between normal and atherosclerotic tissue, of the atheroma itself develops fissures $(13,19)$. The internal elastic lamina and media may be torn apart (16-18). Platelets aggregate at these sites of vascular injury. The platelets release a plethora of substances among which are growth factors (58) and an endoglycosidase which cleaves heparin proteoglycan from the surface of endothelial and smooth space, the smooth muscle cells begin to produce chodroitin sulfate and dermatan sulfate proteoglycan (62). This proteoglycan gradually replaces the fibronectin as the dominant component of the extracellular matrix (62). By day 5 , transforming growth factor beta, the most potent of the growth factors regulating extracellular matrix formation (45), begins to increase substantially in the injured tissue (49). Depending on the area of denudation, endothelial cells cover the injured surface by about day 7 $(63,64)$. If the area of denudation is small (e.g., less than $1 \mathrm{~cm}$. long) intimal hyperplasia does not ensue (65). Thus, there is probably a critical time (5-7 days) or lesion size in 
which endothelial coverage can precede maximum smooth muscle cell proliferation. Conversely, larger areas can remain chronically devoid of endothelial cells (66).

Days 10-120: As the endothelial cells cover the injured blood vessel surface, they cease proliferating, and begin to synthesize heparin proteoglycan (55). Adjacent smooth muscle cells avidly bind the heparin (quiescent smooth muscle cells bind ten times more heparin than proliferating cells) (52). The smooth muscle cells become unresponsive to the proliferative effects of growth factors (51). Since smooth muscle cell proteoglycan synthesis is independent of migration and proliferation, however, extracellular matrix production does not necessarily cease (57). Restoration of blood vessel surface integrity sharply reduces loss of proteoglycan from the injured surface, (67), and proteogycan rapidly accumulates in the myointimal space. The injured blood vessel surface develops the histologic appearance of intimal hyperplasia: smooth muscle cells scattered through a loose extracellular matrix (31).

By two weeks the synthetic smooth muscle cells in the extracellular matrix have begun to revert back to the contractile phenotype $(53,66)$. There is, however, a striking difference in behaviour depending upon their physical location intimal smooth muscle cells adjoining a deendothelialized surface have fifty times the proliferation rate of those adjacent to a reendothelialized surface (59). By 6 weeks the volume of myofilaments as percentage of cytoplasmic volume (an index of the contractile phenotype) is midway in its return to its value in the resting state. Depending on the magnitude of injury and possibly other factors, intimal hyperplasia reaches a peak at 4-12 weeks (68-71). As smooth muscle cell proliferation diminishes while proteoglycan synthesis continues, the volume of intimal hyperplasia mass occupied by the smooth muscle cell diminishes (69). The return to contractile phenotype is paralleled by a change in the extracellular matrix: ${ }^{1}$ proteoglycan is gradually replaced by collagen (72). In the relatively normal segments of the vessel, this fibrotic remodelling and the restoration of responsiveness to vasoconstrictive stimuli $(73,74)$ may contribute to the angiographic phenomenon of narrowing in normal segment proximal to the diseased segment, which often accompanies restenosis (4).

Day 120-135: By 180 days the relative percentage of contractile phenotype smooth muscle cells has returned to the resting state level $(53,75)$, and the restenotic response is probably largely complete. In the small minority of blood vessels with areas of chronic endothelial denudation, however, smooth muscle proliferation continues at levels many times of the resting state $6 \%$ per day vs resting $0.1 \%$ per day) (59). Thus in a small percentage of lesions restenosis may become evident between six and 12 months (3).

\section{POTENTIAL DIRECTIONS FOR PREVENTION OF RESTEHOSIS}

- The preceding hypothetical construct suggest that there are many rate-limiting steps in the development of intimal hyperplasia and by inference, a number of sites for potential intervention. Some of these rate limiting steps have already been tested in clinical trials; no intervention has so far been sufficiently successful to warrant widerspread use. Before discussing possible interventions, therefore, we need to examine critically several potential limitations of previous clinical trials. 1) The relationship of dose and duration of the agent delivered at the injury site may have been inappropriate, for instance, thrombocytopenia substantially inhibits intimal hyperplasia in animals (76), yet antiplatelet agents have been ineffective in man. Since the half-time for platelet aggregation after injury is measured in hours (77), it is possible that a brief, intravenous infusion of a platelet antagonist in this period would be more effective than lower dose, long term oral administration. 2) The timing of drug administration may have been inappropriate. For instance, heparin inhibits intimal hyperplasia in animals, but not in man. Heparin binds growth factors at the injury site early after injury, and may thereby facilitate cell migration and proliferation. Since heparin also inhibits smooth muscle cell proliferation in the third phase of wound healing either late or continued administration of heparin might be much more effective than brief intravenous therapy immediately after injury. 3) It is not always immediately apparent what therapeutic effect is desirable. For instance, given that growth factors accelerate wound healing through stimulation of mesenchymal cell proliferation, it is not clear if this effect should be facilitated or inhibited. Within these limitations, potential therapie and their rationale are listed in Table 3.

TABLE 3: POTENTIAL THERAPIES IN RESTENOSIS

\begin{tabular}{|c|c|c|}
\hline TARGET & EXAMPLES & ACTION \\
\hline \multicolumn{3}{|c|}{ I. INFLAMMATORY PHASE } \\
\hline \multirow[t]{3}{*}{ Platelets } & Aspirin, dipyridamole & $\begin{array}{l}\text { Inhibit adhesion and ag- } \\
\text { gregation }\end{array}$ \\
\hline & Sulotroban & $\begin{array}{l}\text { Block thromboxane recep- } \\
\text { tor }\end{array}$ \\
\hline & Monoclonal antibodies & $\begin{array}{l}\text { Block IIa/IIIb fibrinogen } \\
\text { receptor }\end{array}$ \\
\hline \multirow[t]{3}{*}{ Inflam Cells } & Steriods & $\begin{array}{l}\text { Inhibit accumulation and } \\
\text { activation. }\end{array}$ \\
\hline & Fish oil & Inhibit activation \\
\hline & Cyclosprin A & Inhibit T lymphocytes \\
\hline \multicolumn{3}{|c|}{ II. GRANULATION PHASE } \\
\hline SM cell & Vincristine/actinomycin & Destroy SMCs \\
\hline SMC receptor & $\begin{array}{l}\text { Heparin } \\
\text { Trapidil }\end{array}$ & $\begin{array}{l}\text { Inhibit SMC modulation } \\
\text { Antagonize PDGF action }\end{array}$ \\
\hline \multicolumn{3}{|c|}{ III. MATRIX REMODELLING PHASE } \\
\hline Synthetic SMC & Colchicine, DSMO & $\begin{array}{l}\text { Reduce secretory or- } \\
\text { ganelles }\end{array}$ \\
\hline Mesenchymal cells & Retinoids & Reduce matrix synthesis \\
\hline
\end{tabular}


THE INFLAMMATORY PHASE: PLATELET INHIBITORS AND AHTIIHFLAMMATORY AGENTS

$U$ The biologic rationale for platelet antagonists is strong. Platelets initiate the healing response to injury (7678) by release of growth factors (including PDGF and TGF beta) from their alpha granules. In addition they are the source of the endoglycosidase that cleaves heparin from the smooth muscle cells, a potentially critical step in smooth cell phenotypic modulation. Further, thrombocytopenia inhibits intimal hyperplasia after vascular injury in atherosclerotic animals possibly through reduced smooth muscle migration to the injury site (79). Carefully conducted clinical trials of aspirin and dipyridamole, however, have been unsuccessful. Schwartz et al reported a randomized blind placebo controlled study of long term oral aspirin-dipyridamole combination $(330 \mathrm{mg}-75 \mathrm{mg}$ tid) combined with a 24 hour interval of intravenous dipyridamole in 376 patients. At 4-7 months post-PTCA, followup angiography showed that $38 \%$ of treated patients and $39 \%$ of placebo patients had restenosis (80). Thronton et al compared long term oral $325 \mathrm{mg}$ aspirin to a coumadin dose sufficient to maintain 2-2.5 times the control value. The restenosis rate in the 126 patients aspirin cohort was $27 \%$, a level not different from the coumadin-treated group, and within the range of cu rrently reported restenosis rates (81). In addition to the aforementioned limitations of dose and duration, it is possible that these negative results reflect the dual effect of aspirin on throboxane and prostacyclin metabolism. Thromboxane A2 receptor antagonists could circumvent this limitation. Finally, newly developed monoclonal antibodies to platelet receptors, such as the Ilb/IIIa receptor for fibrinogen, producetransient and potent antihemostatic effects. Platelet aggregation can be effectively eliminated, with return over 48 hours, in dose dependent manner (78). The potential value of such therapies has not been tested in man.

The rationale for use of antiflammatory agents is that they inhibit both cell accumulation and/or activation at the injury site. Reduction of the number of activated cells could decrease expression of growth factors, inhibiting the subsequent sequence of smooth muscle cell phenotypic modulation, migration, proliferation and extracellular matrix formation. Cortisol inhibits smooth muscle cell protein synthesis and proliferation in cell culture (82), and the combination of steroids with heparin inhibits smooth muscle cell proliferation in animals (83). Liu et al, however, report that the administration of steroids for one week post PTCA did not reduce the restenosis rate (84). Cyclospirin A inhibits T-lymphocyte activation. These cells may regulate the expression of growth factors by smooth muscle cells after vascular injury (85). Cyclospirin A produced a highly significant reduction in both smooth muscle cell number and extracellular matrix production in the denuded rat endothelium (85). Omega 3 fatty acids, which have both antiinflammatory and antiplatelet actions, have been reported to reduce restenosis in some clinical trials but not in others (86-90). The potential value of antiinflammmatory agents, therefore, remains entirely unresolved.

\section{THE GRANULATION PHASE: CYTOTOXICS AND GROWTH FAC- TOR ANTAGONISTS}

- The rationale for use of cytotoxics is that some can destroy smooth muscle cells. A logical choice in this category might be agents shown to be effective in myosarcomas. The combination of actinomycin and vincristine is quite effective in destroying proliferating smooth muscle cells. Barath et al used that combination to destroy proliferating malignant smooth muscle cells after balloon denudation in animals (91). There have been no clinical trials of cytotoxic agents in restenosis.

The rationale for use of growth factor antagonists is that they could inhibit smooth muscle cell modulation, migration, or proliferation. Proliferating smooth muscle eels at 2 weeks post balloon injury produce ten times the amount of PDGF as non proliferating cells (39), and messenger RNA tissue concentrations of its competence factor, IGF-1 are equally increased in injured areas (48). Monoclonal antibodies and antagonists to receptors for various growth factors may inhibit cell growth in vitro (92), but none have yet been tested in animals or man. Heparin is particularly promising because it effectively prevents smooth muscle proliferation in cell culture, and intimal hyperplasia in animals $(93,94)$. Nevertheless heparin is also a potent stimulus to extracellular matrix production. The antiproliferative and anticoagulant domains of heparin are different, so that it is possible to construct an antiproliferative, non-anticoagulant form of heparin (95). Thus, although heparin has not yet been shown to be effective in preventing restenosis in man (96), it is possible that ongoing clinical trials with higher doses of nonanticoagulant heparin may prove to be effective. Finally, angiotensin-converting enzyme inhibitors have recently been reported to prevent myointimal proliferation after vascular injury in rats (97), presumably through their ability to block angiotensinll-mediated induction of PDGFA gene expression in aortic smooth muscle cells (98). Their potential role in humans remains to be defined.

\section{THE EXTRACELLULAR MATRIX PHASE ANTISECRETORY AGENTS}

- There are a variety of unrelated agents which are capable of inhibiting synthesis of extracellular matrix. Both colchicine (99) and DMSO (100) reduce the number of secretory organelles in smooth muscle cells. This effect 
is associated with significant reduction in extracellular matrix production. Retinoids also inhibit extracellular matrix production in the animal model $(101,102)$, and are being tested in fibroproliferative disorders such as keloid formation (102). Possibly because the role of the extracellular matrix in restenosis has not been recognized, the antisecretory agents have not yet been formally tested for prevention of restenosis.

\section{OTHER MEANS OF PREVENTING RESTEHOSIS}

- There are a number of agents that may prevent intimal hyperplasia through actions that are riot clearly understood. Lovastatin, prostaglandin and calcium antagonists, for instance, all inhibit smooth muscle cell proliferation and/or migration (103-108). Vascular stents, while not preventing the intimal hyperplasia component of restenosis, eliminate elastic recoil and may be particularly effective when the residual coronary lumen diameter is large, e.g., $>3 \mathrm{~mm}$.

Even with a clear understanding of the pathogenesis of restenosis and the subsequent development of pharmacologic methods to reduce the hyperplasia response to injury, it seems unlikely that this effect alone will resolve the problem of restenosis. Assuming restenosis is due to the combined effects of intimal hyperplasia and elastic recoil, inhibition of intimal hyperplasia will probably be most effective when combined with partial or complete removal of atheroma mass. Several methods for removing atheroma mass including atherectomy (109) and excimer laser angioplasty $(110,111)$ are now in large scale coronary angioplasty trials. Atherectomy requires use of a balloon and does not eliminate the stretching stimulus; the excimer laser and other mechanical ablation devices (112) do not require a balloon. The resolution of restenosis most likely will be achieved, we believe, by the combined effects of inhibition of intimal hyperplasia and removal of atheroma mass.

\section{ACKNOWLEDGEMENTS:}

- The authors wish to express their appreciation to the Medallions, United Hostesses and Grand Foundations for financial support, and to Ms. Dwana Williams for word processing assistance.

\section{REFERENCES}

1. Brown P W (1986) The outlook for the coronary angioplasty industry. Hambrect and Quist Inc

2. Holmes DR, Vlietstra R, Smith H, Vetrovec G W, Kent KM, Cowley M.I, Faxon DP, Gruentzig AR, Kelsey SF, Detre KM, VanRanden MJ, Mock MB(1984) Restenosis after percutaneous transluminal coronary angioplasty (PTCA) a report from the PTCA Registry of the National Heart, Lung and
Blood Institute. Am J Cardiol 53:77C-81C

3. Nobuyoshi M, Kimura T, Noksaka H, Mioka S, Ueno K, Yokoi H, Hamasaki N, Hiriuchi H, Ohishi H (1988) Retsenosis after successful percutaneous transluminal coronary angioplasty serial angiographic follow-up of 229 patients. JACC 12:616-623

4. Serruys PW, Luijten HE, Beatt KJ, GeuskensR, deFeyter PJ, van den Brand $\mathrm{M}$, Reiber JHC, Katen $\mathrm{Hj}$, van Es GS, Hugenholtz PG(1988) Incidence of restenosis after successful coronary angioplasty a time related phenomenon. A quantitative angiographic study in 342 consecutive patients at 1, 2, and 3 months. Circ 77:361-372

5. Val PG, Bourassa MG, David PR, Bonan R, Crepeau J, Dyrda I, Lesperance J (1987) Restenosis after successful percutaneous transluminal coronary angioplasty the Montreal Heart Institute Experience. Am J Cardiol 60:50B-55B

6. Bertrand ME, Lablanche JM, Fourrier JL, Gommeaux A, Ruel M (1989) Relation to restenosis after percutaneous thansluminal coronary angioplasty to vasomotion of the dilated coronary arterial segment. Am J Cardiol 63:277-281

7. King SB (January 1989) Information from the Emory University PTCA Data Base, presented at the 20th Annual American College of Cardiology Conference at Snowmass

8. Ellis SG, Roubin GS, King SB, Douglas JS, Cox WR (1989) Important of stenosis morphology in the estimation of restenosis risk after elective percutaneous transluminal coronary angioplasty. Am J Cardiol 63:30-34

9. Forrester JS, Litvack F, Grundfest W, Hickey A (1987) A perspective of coronary disease seen through the arteries of living man. Circ 75:505-513

10. Uchida Y, Hasegawa K, Kawamura K, Shibuya I (1989) Angioscopic observation of the coronary luminal changes induced by percutaneous transluminal coronary angioplasty. AHJ 177:769-776

11. Mizuno Y, Miyamoto A., Shibuya T, Okamoto Y, Satomura K, Isojima K, Horiuchi K, Nakamura H, Arai T, Kikuchi M (1988) Changes of angioscopic macromorphology following coronary angioplasty. Circ (Suppl 11) 289A

12. Austin GE, Ratliff NB, Hollman J, Tabeil S, Phillips D (1985) Intimal proliferation of smooth muscle cells as an explanation for reccurent coronary artery stenosis after percutaneous transluminal coronary angioplasty. JACC 6:369-375

13. Block P, Myler R, Stertzer S, Fallen J (1981) Morphology after transluminal angioplasty in human beings. NEJM 305:382-385

14. Giraldo AA, Esposo OM, Meis JM (1985)Intimal hyperplasia as a cause of restenosis after percutaneous transluminal coronary angioplasty. Arch Pathol Lab Med 109:173-175

15. Ueda M, Becker AE, Fujimoto T (1987) Pathologic changes induced by repeated percutaneous transluminal coronary angioplasty. Br Heart J 586:35-43

16. Gravanis MB, Roubin GS (1989) Histopathologic phenomena at the site of percutaneous transluminal coronary angioplasty. Human Pathology 20:477-485

17. Saner HE, Goebel FL, Salmonowitz E, Erlien DA, Edwards JE (1985) The diseasefree will in coronary atherosclerosis Its relation to degree of obstruction. JACC 6:1096-1099

18. Waller BF (1988) Morphologic correlates of coronary angiographic patterns at the site of percutaneous transluminal coronary angioplasty. Clin Cardiol 11:817-822 
19. Potkin BN, Roberts WC (1988) Effects of percutaneous transluminal coronary angioplasty on atherosclerotic plaques and relation of plaque composition and arterial size to outcome. Am J Cardiol 62:41-50

20. Kochi T, Takebayashi S, Block PC, Hiroki T, Nobuyoshi M (1987) Arterial changes after percutaneous transluminal coronary angioplasty results at autopsy. JACC 10:592-599

21. deMorais CF, Lopes EA, Checchi H, Arie S, Poileggi F (1986) Percutaneous transluminal coronary angioplasty histopathological analysis of nine necropsy cases. Virchows $\operatorname{Arch}(\mathrm{A})$ 410:195-202

22. Soward AL, Essed CE, Serruys PW (1985) Coronary arterial findings after accedental death immediately after successful percutaneous transluminal coronary angioplasty. Am J Cardiol 56:794-795

23. Schneider J, Gruntzig A (1985) ercutaneous transluminal coronary angioplasty morphological findings in 3 patients. Pathol Res Pract 180:348-352

24. Mizuno K, Kurita A, Imazeki N (1984) Pathological findings after percutaneous transluminal coronary angioplasty. $\mathrm{Br}$ Heart J 52:588-590

25. Bruneval P, Guermonprez JL, Perrier P, Carpentier A, Camilleri JP (1986) Coronary artery restenosis following transluminal coronary angioplasty. Arch Pathol Lab Med 110:1186-1187

26. Walter, B (1989) "Crackers, breakers, stretchers, drillers, scrapers, shavers, burers, welders, and melters" - the future treatment of atherosclerotic coronary artery disease? a clinical-morphologic assessment. JACC 13:969-987

27. Sanborn TA, Faxon, DP, Haudenschild C, Gottsman SB, Ryan TJ (1983) The mechanism of transluminal angioplasty evidence for formation of aneurysms in experimental atherosclerosis. Circulation 68:1136-1140

28. Steele PM, ChesebroJH, Stansos AW, HolmesDR, Dewanje MK, Badimon L, Fuster V (1985) Balloon angioplasty natural history of the pathophysioogic response to injury in a .pig model. Circ Res 57:105-112

29. Leung DY, Glagov S, Mathews MB (1976) Cyclic stretching stimulates synthesis of matrix components by arterial smooth muscle cells in vitro. Science 191:475-477

30. Clowes AW, Clowes MM, Fingerle J, Reidy MA (1989) Kinetics of cellular proliferation after arterial injury V. Role of acute distention in the induction of smooth muscle proliferation. Lab Invest! 603:360-364

31. Simpson JB, Selmon MR, Robertson GC, Cipriano PR, Haiyden WG, Johnson DE, Fogarty TJ (1988) Transluminal atherectomy for occlusive peripheral vascular disease. Am J Cardiol 61:96G-101G

32. Greisler HP, Ellingen J, Schwarc TH, Golan J, Raymond RM, Kim DU (1987) Arterial regeneration over polydioxanone prostheses in the rabbit. Arch Surg 122:715721

33. Clark RAF (1988) Overview and general considerations of wound repair. In the Molecular and Cellular Biology of Wound Repair. Clark RAF and Henson PM, eds. Plenum Press

34. Brown GL, Nanney LB, Griffen J, et al (1989) Enhancement of wound healing by topical treatment with epidermal growth factor. N Engl J Med 321:76-9

35. Barbul A, Pines E, Caldwell M, Hunt TK, eds (1988) Growth factors and other aspects of wound healing: biological and clinical implications. Progress in Cinical and Biological Research 266, New York, Alan R. Liss

36. Hjelmeland LM, Harvey AK (1988) Growth factors solube mediators of wound repair and ocular fibrosis. Birth Defects 24:87-102 .

37. Knigthon DR, Fiegel VD, Austin LL, Ciresi KF, Butler EL (1986) Classification and treatment of chronic nonhealing wounds. Ann Surg 204:322-330

38. Ross R, Raines EW, Bowen-Pope DF 1988 The biology of platelet-derived growth factor. Cell 46:155-169

39. Walker LN, Bowen-Pope DF, Ross R, Reidy MA (1986) Production of platelet-derived growth factor-like molecules by cultured arterial smooth muscle cells accompanies proliferation after injury. Proc. Natl. Acad. Sci 83:7311-7315

40. Folkman J, Klagsbrun M (1987) Angiogenic Factors. Science 235:442-447

41. Stiles CD, Capone GT, Sher CD, Antoniades HN, Van Wyk JJ, Pledger WJ (1979) Dual control of cell growth by somatomedins and platelet-derived growth factor. Proc Natl Acad Sci 76:1279-1283

42. Waterfield MD (1989) Epidermal growth factor and related molecules. Lancet June 1243-1246

43. Spencer EM, Skover G, Hunt TK (1988) Somatomedins Do they play a pivotal role in wound healing? Growth Factors and Other Aspects of Wound Healing. Biological and Clinical Implications 103-116

44. Roberts AB, Flanders KC, Kondaiah P, Thompson NL, Van Obberghen-Schilling E, Wakelfield L, Rossi P, De Crombmgghe B, Heine U, Sporn MB (1988) Transforming growth factor beta: Biochemistry and roles in embryogenesis, tissue repair and remodelling and carcinogenesis. In Recent Progress in Hormone Research, Vol. 44, Academi Press

45. Sprugel KH, McPherson JM, Clowes AW, Ross R (1988) The effects of different growth factors in subcutaneous wound chambers. In Growth Factors and Other Aspects of Wound Healing Biological and Clinical Implications, p. 7791, Alan R. Liss

46. Chen JK, Hoshi H, McKeehan WL (1987) Transforming growth factor type beta specifically stimulates synthesis of prteoglycan in human adult arterial smooth muscle cells. Proc Natl Acad Sci 84:5287-5291

47. Ignotz RA, Massaque J (1986) Transforming growth factorbeta stimulates the expression of fibronectin and collagen and their incorporation into the extracellular matrix. J Biol Chem 261:4337-4345

48. Cercek B, Fishbein MC, Forrester JS, Helfant RH, Fagin JA (in press, 1990) Induction of IGF-1 m-RNA in rat aorta after balloon denudation. Circ Res

49. Cromack DT, Sporn MB, Roberts AB, Merino MJ, Dart LL, Norton JA (1988) Transforming growth factor beta levels in rat wound chambers. J Surg Res 42:622-628

50. Campbell GR, Campbell JH, Manderson JA, Horrigan S, Rennick RE (1988) Arterial Smooth Muscle. A multifunctional mesenchymal cell Arch Pathol Lab Med 112:977-986

51. Castellot JJ, Wright TC, Karnovsky MJ (1987) Regulation of vascular smooth muscle cell growth by heparan sulfates. In Seminars in Thrombosis and Hemostasis 13:489-503

52. Castellot JJ, Addonizio ML, Rosenberg RD, Karnovsky MJ (1984) Cultured endothelial cells produce a heparin-like 
inhibitor of smooth muscle cell growth. J Cell Biol 90:372-379

53. Campbell JH, Campbell GR (1986) Endothelial cell influences on vascular smooth muscle phenotype. Ann Rev Physiol 48295-306

54. McCaffrey TA, Falcone DJ, Brayton CF, Agarwal LA, Welt FGP, Weksler BB (1989) Transforming growth factor-beta activity is potentiated by heparin via dissociation of the transforming growth factor beta/alpha2-macroglobulin inactive complex. Cell Biol 109441-448

55. Wight TN (1989) Cell biology of arterial proteoglycans. Arteriosclerosis 91-20

56. Bassols A, Massaque J (1988) Transforming growth factor beta regulates the expression and structure of extracellular matrix chondrotin/dermatan sulfate proteoglycans. J Biol Chem 26:33039-3045

57. Kinsella MG, Wight TN (1986) Modulation of sulfated proteoglycan synthesis by bovine aortic endothelial cells during migration. J Cell Biol 102:678-687

58. Lobb RR (1983) Clinical applications of heparin-binding growth factors. European Journal of Clinical Investigation $18: 321-336$

59. Clowes AW, Reidy MA, Clowes MM (1983) kinetics of cellular proliferatio after arterial injury. I. Smooth muscle growth in the absence of endothelium. Lab Invest 49:327-333

60. Holund B, Clemmensen K, Junker P, Lyon H (1982) Fibronectin in experimental granulation tissue. Acta Pathol Microbiol Immunol Scand 90159-165

61. Anseth A (1961) Glycosaminoglycans in corneal regeneration. Exp Eye Res 1:122-127

62. Bently JR (1967) Rate of chondroitin sulfate formation in wound healing. Ann Surg 165:186-191

63. Clowes AW, Schwartz SM (1985) Significance of quiescent smooth muscle migration in the injured rat carotid artery. Circ Res 56:139-145

64. Fishman JA, Ryan GB, Karnovsky MJ (1975) Endothelial regeneration in the rat carotid artery and the significance of endothelial denudation in the pathogenesis of myointimal thickening. Lab Invest 32:339-351

65. Reidy MA, Schwartz SM (1981) Endothelial regeneration III. Time course of intimal change after small defined injury to rat endothelium. Lab Invest 44:301

66. Clowes AW, Clowes MM, Reidy MA (1986) Kinetics of cellular proliferation after arterial injury. III. Endothelial and smooth muscle growth in chronically denuded vessels. Lab Invest 54:295-303

67. Alvai M, Moore S (1985) Glycosaminoglycan composition and biosynthesis in the endothelium-covered neointima and de-endothelialized rabbit aorta. Exp Mol Pathol 42:389-400

68. Stemerman MB, Spaet TH, Pitlick F, Cintron J, Lejnieks, Tiell ML (1977) Intimal Healing: The pattern of reendothelialization and intimal thickening. Am J Pathol 7:125-137

69. Clowes AW, Reidy MA, Clowes MM (1983) Mechanism of stenosis after arterial injury. Lab Invest 49:208-215

70. Schwartz SM, Campbell GR, Campbell JH (1986) Replication of smooth muscle cells in vascular disease. Circ Res 58:427-444

71. ClowesAW,KirkmanTR,RiedyMA(1986) Mechanisms of arterial graft healing. Rapid transmural capillary ingrowth provides a source of intimal endothelium and smooth muscle in porous PTFE prostheses. Am J Pathol 123220-230
72. Diegelmann RF, Rothkopf LC, Cohen IK (1975) Measurement of collagen biosynthesis during wound healing. J Surg Res 19239-243

73. Consigny PM, Tulenko TN, Nichosia RF (1986) Immediate and long term effects of angioplasty-balloon dilation on normal rabbit iliac artery. Arteriosclerosis 6:265-276

74. Castaneda-Zuniga WR, Laerum F, Rysavy J, Rusnak B, Amplatz K. (1982) Paralysis of arteries by intraluminal balloon dilation. Radiology 144:75-76

75. Manderson JA, Mosse PRL, Safstrom JA, Ypung SB, Campbell GR (1989) Balloon catheter injury to rabbit carotid artery I. Changes in smooth muscle phenotype. Arteriosclerosis 9:289-296

76. Minar E, Ehringer H, Ahmadi R, Dudczak R, Leitha T, Koppensteiner R, Jung M, Stumpflen A (1989) Platelet deposition at angioplasty sites and its relation to restenosis in human iliac andfemoropopliteal arteries. Radiology 170:767772

77. Wilentz JR, Sanborn TA, Hundenschild CC, Valeri CR, Ryan TJ, Faxon DP (1989) Platelet accumulation in experimental angioplasty time course and relation to vascular injury. Circulation 75:636-642

78. Harker LA (1989) Role of platelets and thrombosis of acute occlusion and restenosis after angioplasty. Am J Cardiol 60:20B-28B

79. Fingerle J, Johnsos R, Clowes AW, Majesky M W, Reidy MA (1989) Role of platelets in smooth muscle cell proliferation and migration after vascular injury in rat carotid artery. Proc Natl Acad Sci 86:8412-8416

80. Schwartz L, Bourassa MG, Lesperance J, Aldridge HE, Kazim F, Salvatori VA, Henderson M, Bonan R, David PR (1988) Aspirin and dipyridamole in the prevention of restenosis after percutaneous transluminal coronary angioplasty. NEJM 318:1714-1719

81. Thronton MA, Gruentzig AR, Hollman J, King SB, Douglas JS (1984) Coumadin and aspirin in prevention of recurrence after transluminal coronary angioplasty a randomized study. Circ 69:721-727

82. Jarvelainen H, Halme T, Ronnemaa (1982) Effect of cortisol on the proliferation and protein synthesis of human arotic smooth muscle cells in culture. Acta Med Scand 660 (Suppl) $114-122$

83. Gordon JB, Berk BC, Bettman, Selwyn AP, Rennke H, Alexander RW (1987) Vascular smooth muscle proliferation following balloon injury is synergistically inhibited by low molecular weight heparin and hydrocortisone. Circ 76 (suppl IV)IV-213

84. Liu W, Robin GS, King SB (1989) Research on coronary artery stenosis. Restenosis after coronary angioplasty. Potential biological determinants and role of intimal hyperplasia. Circ 79:1374-1387

85. Jonasson L, Holm J, Hansson GK (1988) Cyclosporin A inhibits smooth muscle proliferation in the vascular response to injury. Proc Natl Acad Sci 85:2303-2306

86. Grigg LE, Kay T, Manolas EG, Hunt D, Valentine PA (1987) Does Max-EPA lower the risk of restenosis after PTCA a prospective randomized trial. Circ 76IV-214

87. Reis GJ, Boucher TM, Sipperly ME, Silverman DI, McCabe CH, Bairn DS, Sacks FM, Grossman W, Pasternak RC (July 1989) Randomised trial of fish oil for prevention of restenosis 
after coronary angioplasty. Lancet

88. Dehmer GJ, Popma JJ, van den Berg EK, et al (1988) Reduction in the rate of early restenosis after coronary angioplasty by a diet supplemented with n-3 fatty acids. NEJM 391:733-740

89. Slack JD, Pinkerton CA, Van Tassel J, et al (1987) Can oral fish oil supplement minimize restenosis after percutaneous transluminal coronary angioplasty? JACC 9 (suppl)64A

90. Milner MR, Gallino RA, Leffingwell A, Pichard AD, Rosenberg J (1988) High dose omega-3 fatty acid supplmentation reduces clinical restenosis after coronary angioplasty. Circ 78 (suppl 11)634

91. Barath P, Arakawa K, Cao J, Fishbein M, Fagin J, Lusis A, Forrester J (1989) Low dose of antitumor agents prevents smooth musclle cell proliferation after endothelial injury. JACC 13:252A

92. Danielpour D, Dart LL, Flanders KC, Roberts AB, Sporn MB (1989) Immunodetection and quantitation of the two forms of transforming growth factor-beta (TGF-betal and TGF-beta2) secreted by cells in culture. Journal of Cellular Physiology 138:79-86

93. Clowes AW, ClowesMM (1985) Kinetic of cellular proliferation after arterial injury II Inhibition of smooth muscle growth by heparin Lab Invest 52:611-616

94. Reidy MA (1985) Biology of Disease. A reassessment of endothelial injury and arterial lesion formation. Lab Invest; 53:513-520

95. PaulR, Herbert JM, Maffrand, Lansen J, Modal G, Pereillo, Gordon Jl (1987) Inhibition of vascular smooth muscle cell proliferation in culture by pentosan polysulphate and related compounds. Thtomb Res 46:793-801.

96. Ellis SG, Roubin GS, Wilenz J, Lin S, Douglas JS Jr, King SB (1987) Results of a randomized trial of heparin and aspirin vs aspirin alone for prevention of acute closure and restenosis after angioplasty (PTCA). Circulation 76 (suppl IV).

97. Powell JS, Clozel P, Muller RKM, Kuhn H, Hefti F, Hossang M, Baumgartner HR (1989) Inhibitors of angiotensin-converting enzyme prevent myointimal proliferation after vascular injury. Science 245:186-188.

98. Naftilan AJ, Pratt RE, Dzau VJ (1989) Induction of plateletderived growth factor A-chain and c-myc gene expressions by angiotensin II in cultured rat vascular smooth muscle cells. J Clin Invest 83:1419-1424.

99. Chaldakov GN, Vankov VN (1986) Morphological aspects of secretion in the arterial smooth muscle cell, with reference to the Golgi complex and microtubular cytoskeleton. Atherosclerosis 61:175-192.

lOQKatsuda S, Okada Y, Nakanishi I, Tanaka J (1988) Inhibitory effect of dimethyl sulfoxide on the proliferation of cultured arterial smooth muscle cells relationship to the cytoplasmic microtubules. Experimental and Molecular Pathology 48:4858.

1OLDaly TJ, Weston WL (1986) Retinoid effects on fibroblast proliferation and collagen synthesis in vitro and on fibrotic disease in vivo. Journal of American Academy of Dermatology 15:900-902.

1OZPanabiere-Castaings Mil (1988) Retinoic acid in in the treatment of keloids. Journal of Dermatologic Surgery and Oncology 14:1275-1276.

103.Sahni R, Maniet AR, Voci G, Banka VS (1989) Prevention of restenosis by lovastatin. (Abstract) Circ; 80(4)11-65.

104.Morisaki N, Kanzaki T, Motoyama N, Saito Y, Yoshida S (1988) Cell cycle-dependent inhibition of DNA synthesis by prostaglandin 12 in cultured rabbit aortic smooth muscle cells. Atherosclerosis 71:165-171.

105.Nilsson J, Olsson AG (1984) Prostaglandin El inhibits DNA synthesis in arterial smooth muscle cells stimulated with platelet-derived growth factor. Atherosclerosis 53:77-82.

106.Nomoto A, Hirosumi J, Sekiguchi C, Mutoh S, Yamaguchi I, Aoki H (1987) Antiatherogenic activity of FR 34235 (Nilvadipine), a new potent calcium antagonist Effect on cuff induced intimal thickening of rabbit carotid artery. Atherosclerosis 64:255-261.

107.Nilsson J, Sjolund M, Palmberg L, VonEuler AM, Jonzon, Thyberg $\mathrm{J}$ The calcium antagonist nifedipine inhibits arterial smooth muscle proliferation. Atherosclerosis 58:109-122.

108.Betz E, Hammerle D, Viele D, (1984) Ca2-(--entry blockers and atherosclerosis. Int. Angiology 3:33.

109.Simpson JB, Roberson GC, Selmon MR, Sipperly ME, Braden, Hinohara T (1989) Restenosis following successful directional coronary atherectomy. Circ 80(4):2311A.

110.Litvack F, Grundfest WS, Goldenberg T, Laudenberg J, Forrester J (1989) Percutaneous excimer laser angioplasty of aortocoronary saphenous vein grafts. J Am Coll Cardiol 14:803-808.

111.Litvack F, Grundfest W, Eigler N, Tsoi D, Goldenberg T, Laudenslager J, Forrester J (1989) Percutaneous excimer laser coronary angioplasty. Lancet 11102-103.

112,0'Neill WW, Friedman HZ, Cragg D, Strzelecki R, Gangadharan V, Levine AB, Ramos RG (1989) Initial clinical experience and early follow-up of patients undergoing mechanical rotary endarterectomy. Circ 80(4):2318A.

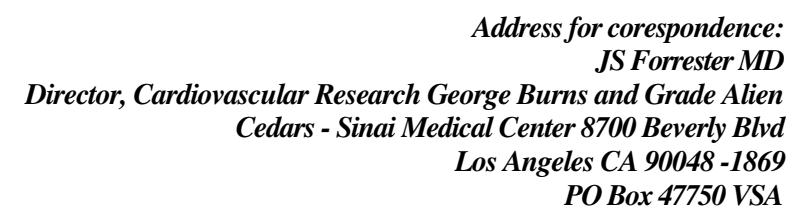

Address for corespondence: JS Forrester MD ascular Research George Burns and Grade Alien Los Angeles CA 90048 -1869 PO Box 47750 VSA 